\title{
RETROLENTAL FIBROPLASIA IN ASSOCIATION WITH MENTAL DEFECT*
}

\author{
BY \\ CYRIL E. WILLIAMS \\ Fountain Hospital, Tooting, London, S.W.17
}

RETROLENTAL fibroplasia is a major cause of blindness in children. It is usually found in premature children; that is to say, in those with a birthweight of under $5 \frac{1}{2} \mathrm{lb}(2,500 \mathrm{~g}$.). In the years that followed Terry's original description the incidence of the disease rose steeply and alarmingly. Krause (1955) has estimated that 10,000 children are partly or completely blind from retrolental fibroplasia in the United States of America and that half of all blind children under 7 years of age are blind because of this condition. A vast literature soon grew up around the subject and a great many possible causes for the condition were investigated, but it was not until 1951 that Campbell, in Australia, showed that the condition occurred in premature children who were nursed in high concentrations of oxygen; when she curtailed the administration of oxygen, no further cases occurred. These findings were shortly confirmed everywhere and the role of oxygen in the production of most of the cases of retrolental fibroplasia was established beyond doubt. Thus, in the majority of cases, retrolental fibroplasia is a disease of the eyes induced in premature babies by the administration of excessive amounts of oxygen.

\section{Review of the Literature}

Many writers have described a high incidence of mental retardation in association with retrolental fibroplasia. Krause (1946) published an account of eighteen cases of retrolental fibroplasia, of which three had congenital hydrocephalus, one microcephaly, and three more were grossly mentally defective; a further five were probably mentally subnormal, but at that time they were too young for a reliable diagnosis of mental defect. However, 9 years later Krause (1955) published a review of 107 cases: nine were dead, 16 per cent. were of very low mentality, and 20 per cent. were of poor mentality.

Kerr and Scott (1954) found that seven out of twenty cases (35 per cent.) were mentally subnormal, and Forrester (1955), describing the Manchester epidemic of this disease, thought that 20 per cent. were slightly and 10 per cent. grossly retarded. Bjelkhagen (1952) said that fourteen out of 38 cases 
found in Sweden were mentally defective; the intelligence in eleven was normal and in the remainder it was uncertain. Potter (1954) reviewed 283 cases of blindness that he had examined for the Royal National Institute for the Blind between October, 1951, and December, 1953; he found 151 cases of retrolental fibroplasia, and of these 26.6 per cent. were retarded and 20.3 per cent. were mentally defective, so that only 53.1 per cent. of his group were considered to be of normal intelligence.

\section{Ineducability and Retrolental Fibroplasia}

Through the courtesy of the Chief Education Officer of the Royal National Institute for the Blind, I have been able to review the admissions to and discharges from the Sunshine Homes over the past 10 years. These Sunshine Homes admit about one-third of the blind children in England and Wales for care and early training. The age at admission is usually between 2 and 5 years and if suitable the blind children remain at these homes until they are 7 years old, when they go on to schools for the blind in the normal educational system.

Table I shows that, of 211 children born between 1946 and 1952 who had retrolental fibroplasia and were admitted to the Sunshine Homes, 58 (27.4 per cent.) were ineducable. This group is compared with 294 children blind for reasons other than retrolental fibroplasia of whom 54 (18.2 per cent.) were ineducable. The difference between these figures is significant by the $\mathrm{X}^{2}$ test $\left(\mathrm{X}^{2} 5.75 ; 0.01<P<0.02\right)$. From these figures it is evident that

TABLE I

ANALYSIS OF 505 CASES OF BLINDNESS IN CHILDREN SHOWING NUMBERS REGARDED AS INEDUCABLE

\begin{tabular}{|c|c|c|c|c|c|c|c|}
\hline \multirow{3}{*}{$\begin{array}{l}\text { Year of } \\
\text { Birth }\end{array}$} & \multirow{3}{*}{$\begin{array}{l}\text { Number of } \\
\text { Cases }\end{array}$} & \multirow{3}{*}{$\begin{array}{l}\text { Cases due to } \\
\text { Retrolental } \\
\text { Fibroplasia }\end{array}$} & \multicolumn{5}{|c|}{ Ineducable Blind Children } \\
\hline & & & \multicolumn{2}{|c|}{$\begin{array}{l}\text { (a) Blindess due } \\
\text { to Retrolental } \\
\text { Fibroplasia }\end{array}$} & \multicolumn{2}{|c|}{$\begin{array}{l}\text { (b) Blindness due } \\
\text { to Other } \\
\text { Causes }\end{array}$} & \multirow[t]{2}{*}{ Total } \\
\hline & & & No. & Per cent. & No. & Per cent. & \\
\hline 1946 & 44 & 5 & 1 & 20 & 7 & $17 \cdot 9$ & 8 \\
\hline 1947 & 63 & 13 & 5 & $38 \cdot 4$ & 12 & 24 & 17 \\
\hline 1948 & 66 & 20 & 6 & 30 & 12 & 26 & 18 \\
\hline 1949 & 64 & 45 & 10 & $22 \cdot 2$ & 6 & $31 \cdot 5$ & 16 \\
\hline 1950 & 98 & 50 & 21 & 42 & 8 & $16 \cdot 6$ & 29 \\
\hline 1951 & 101 & 45 & 9 & 20 & 4 & $7 \cdot 1$ & 13 \\
\hline 1952 & 69 & 33 & 6 & $18 \cdot 1$ & 5 & $13 \cdot 8$ & 11 \\
\hline Total & 505 & 211 & 58 & $27 \cdot 4$ & 54 & $18 \cdot 2$ & 112 \\
\hline
\end{tabular}


retrolental fibroplasia cannot be regarded as a disease in which the eyes alone are involved.

Table I also shows the tragic and dramatic rise in the incidence of retrolental fibroplasia in children born between 1946 and 1951, together with the gratifying fall in 1952 which has continued in recent years.

\section{Present Investigation}

A review of the main causes of blindness in the Ellen Terry Home, Reigate, revealed fourteen cases of retrolental fibroplasia. This unit provides care and training for blind imbeciles, who are admitted from all areas of England and Wales. Table II illustrates the causes of blindness in 51 children who were at the home on November 1, 1956. In addition to these fourteen cases of retrolental fibroplasia, there are three more at the Fountain Hospital, six that have been discharged, and one that has died. It is the purpose of this paper to review these 24 cases and to discuss the relationship between mental retardation and retrolental fibroplasia.

TABLE II

MAIN CAUSES OF BLINDNESS IN 51 CHILDREN AT THE ELLEN TERRY HOME ON NOVEMBER 1, 1956

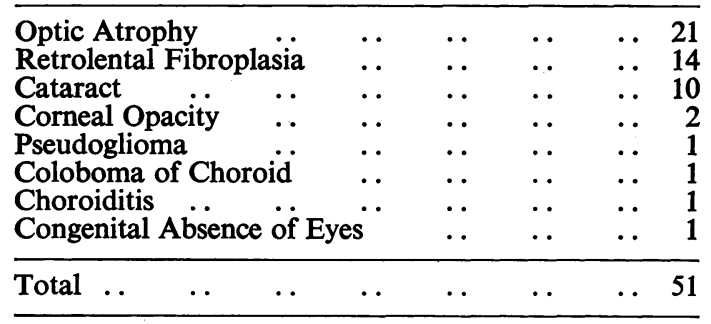

Of the 24 cases 23 were premature. A history of being nursed in oxygen tents is available for eighteen of them, in four there is no such history but they were born at a time when it was routine to nurse premature infants in high concentrations of oxygen, and one child received oxygen by nasal catheter and then only at meal times. The case of the one child who was not premature is given briefly below:

A female infant was born in 1944 after a normal labour; her birthweight was 10-1b 6oz $(4,680 \mathrm{~g}$.). The pregnancy was an illegitimate one and the mother had previously suffered from syphilis, but at the time of our patient's birth her Wassermann reaction was negative and the child's Wassermann reaction has been negative consistently since birth. There is no history of her having been nursed in an oxygen tent, but she is said to have suffered repeated attacks of bronchitis in infancy. Her left eye was enucleated at the Institute of Ophthalmology when she was 15 months old. Section of the enucleated eye showed cyclitis with a matted retrolental mass involving the totally detached retina and a diagnosis of pseudoglioma was made. The section has recently been examined by Prof. Norman Ashton, Director of the Department of Pathology at the Institute, who states that its histological features are consistent with retrolental fibroplasia.

The aetiology of such cases is in doubt. There seem to be two possibilities. First, the eye condition may be due to a congenital defect, e.g. to a persistent 
tunica lentis, and may be associated with other abnormalities such as hydrocephalus. Krause (1946) suggested the term encephalo-ophthalmic dysplasia for such cases, but it is interesting to note that one of his infants, who was of normal birthweight and had retrolental fibroplasia, was of good intelligence. Secondly, as suggested by Patz (1954), the eye condition may be due to the fact that in the immediate neonatal period the oxygen saturation of the blood is 90 per cent. whereas in utero it is only 50 per cent. This change may affect the immature eye and produce vaso-obliteration which is then followed by outgrowths of new vessels and later by retinal detachment. Numerous cases of retrolental fibroplasia in children of normal birthweight are reported in the literature, perhaps the largest being the series reported by Reese and Stepanik (1954), who saw 20 cases with birthweights between 5-lb $(2,270 \mathrm{~g}$.) and 8-lb (3,640 g.), but did not report on their mental level.

Role of Oxygen.-Excessive amounts of oxygen induce retrolental fibroplasia by leading to constriction and perhaps total obliteration of the retinal vessels. When the baby leaves the oxygen tent, this is followed by vasodilatation, outgrowths of new vessels, and fibroblastic proliferation into the vitreous, and subsequently the fibrous tissue contracts to detach the retina. Patz (1954) thought that oxygen led to obliteration of the developing retinal vessels. Ashton, Ward, and Serpell (1954), Bedrossian, Carmichael, and Ritter (1955), and other authors believe that new vessel growth is due to the relative hypoxia which begins on the return of the experimental animal or the premature baby to the normal atmosphere. In other words, Patz thought that $\mathrm{O}_{2}$ exerted a direct toxic effect on the retinal vasculature, whereas the other workers thought its effects were indirect. Bedrossian and others (1955), Forrester (1955), Szewczyk (1952), and other authors advocated returning a child who developed early signs of the condition to high $\mathrm{O}_{2}$ concentrations for a further period, after which the concentrations were slowly reduced.

Table III (opposite) shows the duration of $\mathrm{O}_{2}$ therapy in relation to the degree of mental defect. The numbers here are too small for tests of statistical significance to be applied, but the general impression is that, on the whole, the children most severely affected mentally appear to have been kept in $\mathrm{O}_{2}$ tents for similar periods to the least affected. The concentration of $\mathrm{O}_{2}$ may be more important than the length of time in which it is given, but information on concentration was lacking in all our cases.

The duration of stay in hospital tended to be longer for the more severely defective children, the average duration of stay being 68 days. Only four of our cases were diagnosed as having retrolental fibroplasia while in hospital neonatally.

Both Patz (1954) and Ashton and others (1954), who have induced a disorder analogous to retrolental fibroplasia in experimental animals, have sought carefully for evidence of vascular changes in the brain similar to those in the eyes. They were unable to demonstrate that high concentrations of $\mathrm{O}_{2}$ had any effect on the brains studied. Forrester returned eighteen of 
TABLE III

DURATION OF NEONATAL OXYGEN THERAPY AND DEGREE OF VISUAL AND MENTAL DEFECT IN 25* CASES

\begin{tabular}{l|c|c|c}
\hline Case & $\begin{array}{c}\text { Days in Oxygen } \\
\text { Tent }\end{array}$ & $\begin{array}{c}\text { Degree of } \\
\text { Retrolental } \\
\text { Fibroplasia }\end{array}$ & Classification \\
\hline A. B. & 10 & V & Idiot \\
S. B. & 28 & V & Idiot \\
J. C. & 21 & Idiot \\
M. J. & Nil & Idiot \\
N. P. & 90 & V & Idiot \\
M. S. & 31 & V & Idiot \\
\hline S. C. & Nasal Catheter & V & Imbecile \\
J. H. & 28 & V & Imbecile \\
G. G. & 18 & Imbecile \\
K. A. & 29 & V & Imbecile \\
F. S. & 14 & V & Imbecile \\
J. N. & 21 & V & Imbecile \\
F. N. & 21 & V & Imbecile \\
\hline J. R. & 60 & V & Feebleminded \\
M. H. & 28 & V & Feebleminded \\
G. C. & 25 & V & Feebleminded \\
V. G. & 35 & V & Feebleminded \\
\hline
\end{tabular}

* No details of duration of $\mathrm{O}_{2}$ therapy available in eight cases.

his cases who were developing early signs of the condition to $\mathrm{O}_{2}$ tents for extended periods but none of them was subsequently mentally retarded. Other authors have failed to find any neural lesions resulting from oxygen poisoning.

Kerr and Scott (1954), however, considered that neural damage in these cases resulted from anoxia and showed that their retrolental fibroplasia group experienced many more so-called "anoxic insults" than a control group of premature infants without retrolental fibroplasia. They felt that the high incidence of neural damage in their cases, together with the retrolental fibroplasia, resulted from anoxia and that high oxygen concentrations increased the anoxia by producing vasoconstriction. Seven of the cases under review suffered neonatal anoxia of marked degree. Ingalls, Tedeschi, and Halpern (1952) produced eye lesions very similar to retrolental fibroplasia in mice by subjecting the mothers to anoxia, and observed that hydrocephalus was seen in significant association with the ocular abnormalities thus induced.

\section{Prematurity and Mental Retardation}

King (1950) disputed that there was a special association between retrolental fibroplasia and mental defect and considered that the incidence of backwardness was wholly attributable to the hazards of prematurity. He quoted Hess and Lundeen (1949), who claimed that 10 per cent. of premature 
babies suffer mental retardation. This is a line of approach to the problem which needs to be carefully considered.

Reliable studies of the mentality of premature children are relatively few and most of them invite fairly severe criticism. The literature on the subject has been extensively and excellently reviewed by Alm (1953). Ÿllpo (1919) found that the incidence of imbecility in premature babies was 7.4 per cent., but the expectant mothers and the children in his group were living in Berlin during and after World War I and suffered a high incidence of rickets. Further, the premature babies studied were not a random sample and there were no controls. Many authors (e.g. Douglas, 1956) have commented on the pitfalls in studying the results of prematurity. Lack of adequate controls, or controls not suitably matched for age, sex, social class, etc. are frequent shortcomings observed. Peiper (1937) surveyed nineteen articles dealing with the incidence of severe mental disturbance in premature children, and considered that 5.5 per cent. of cases were so affected. Alm studied 999 premature boys born between 1902 and 1921 and matched them with a control group of 1,002 boys of normal birthweight. He found that 4.8 per cent. of the prematures, as against 1.2 per cent. of the controls, were in institutions and that the great majority of these were in institutions for the mentally defective. However, most studies of prematurity include cases weighing under $5 \frac{1}{2} \mathrm{lb}(2,500 \mathrm{~g}$.) at birth, whereas the majority of cases of retrolental fibroplasia are very much lighter than this. Boyd and Hirst (1955), in reviewing 6,926 babies who weighed $4 \mathrm{lb} 6 \mathrm{oz}(1,950 \mathrm{~g}$.) or less at birth, found that 127 developed retrolental fibroplasia. The incidence of retrolental fibroplasia in children weighing less than $2 \mathrm{lb} 4 \mathrm{oz}(1,000 \mathrm{~g}$.) was $15.3 \mathrm{per}$ cent., while for those between $3 \mathrm{lb} 14 \mathrm{oz}(1,730 \mathrm{~g}$.) and $4 \mathrm{lb} 6 \mathrm{oz}(1,950 \mathrm{~g}$.) the incidence was only 0.2 per cent. That retrolental fibroplasia is associated with extreme prematurity is shown by the Figure (opposite). The birthweights of our series are compared with a control group of 23 children without retrolental fibroplasia, at present in the Fountain Hospital, who weighed less than $5 \mathrm{lb}(2,270 \mathrm{~g}$.) at birth. Zacharias, Reynolds, Chisholm, and King (1954) have shown that, in America between 1934 and 1952, there was a three-fold increase in the number of children weighing $4 \mathrm{lb}(1,800 \mathrm{~g}$.) or less who survived, and it seems reasonable therefore to postulate that a proportion of these had some degree of neural damage or defect associated with prematurity, and that the association of retrolental fibroplasia in some of them might be purely coincidental.

Douglas (1956), in a detailed study, has been following up all the premature children born in the first week of March, 1946. Out of 676 premature babies, he found that six were educationally subnormal, whereas there were only two so affected in his carefully matched group of controls. The numbers are too small to test for significance. However, he states that premature children resulting from uncomplicated pregnancies have consistently greater handicaps than those from which there is a history of toxaemia, antepartum 


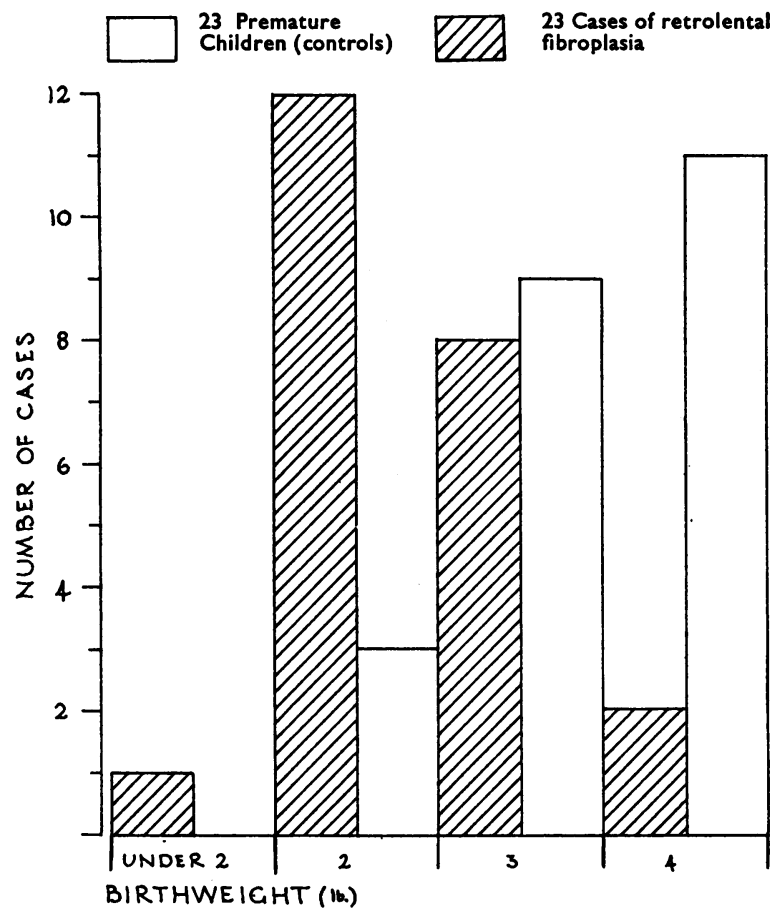

FIGURE.-Birthweights of 46 premature mentally defective children.

haemorrhage, or induced labour. In six of our cases there is a history of antepartum haemorrhage and in three others the mother had toxaemia. In the remaining cases there is no known cause for the prematurity. The report to the Medical Research Council by their conference on retrolental fibroplasia in the United Kingdom (1955) states that the only material factor which was found to have a significantly increased incidence in association with retrolental fibroplasia was antepartum haemorrhage, and, that among the affected babies, there was an excess of those whose mothers had had antepartum haemorrhage of unknown origin. In none of our cases with antepartum haemorrhage was the cause of it ascertained.

In a control group of 23 sighted but defective premature children in the Fountain Hospital, only two had a history of antepartum haemorrhage during their mother's pregnancy, as opposed to six in the retrolental fibroplasia group.

\section{Other Somatic Disorders}

Numerous writers have remarked on the high incidence of other somatic disorders found in cases of retrolental fibroplasia. Ingram and Kerr (1954) reported seventeen cases of retrolental fibroplasia in Edinburgh, of whom five had cerebral diplegia. Forrester had seven cases of mono-, hemi-, or di-plegia in his group. Little (1862) remarked on the importance of prematurity in the disease which now bears his name, and Freud (1897) thought 
that disturbance of foetal-maternal relationship might predispose children to this affliction.

In our group there were no cases of cerebral palsy, but this may well be due to the fact that the majority of our cases are selected for the Ellen Terry Home on the basis of being trainable. Where a gross physical handicap is added to mental backwardness and blindness it is unlikely that such a child would have progressed sufficiently for a local authority to consider it worth while to refer him for admission.

Congenital heart disease has been reported in several cases; two of our group have heart lesions. Skeletal abnormalities are also not rare, but only one of our cases has a significant lesion (talipes equino varus). One boy has webbed toes, but so had his father; another had double toe nails on one toe. Epilepsy was absent from our series and from most others, though one child was reported to have seizures between the ages of 2 days and 5 months.

Two further facts in relation to this problem need to be mentioned:

(1) To quote Douglas (1956): "Prematures tend to be restless, irritable, and lacking in concentration...." and thus do less well educationally.

On the other hand, his group of premature children spent $3 \frac{1}{2}$ times as many days in hospital in the first 2 years as his control group.

(2) Children who lack one of the senses are especially gravely handicapped so that they may appear less intelligent than they are, having lacked appropriate stimulation. Krause (1955) remarks on the fact that the number of children with retrolental fibroplasia in his series, who were considered to be mentally defective, grew smaller with each year. He attributes this to the changing attitude of parents and teachers. Initially he found that blind children were either rejected by their parents at an early age and put into institutions or that the exact opposite happened so that they were overprotected. When better provision was made for the training of both children and their parents, the incidence of backward children fell.

\section{Conclusion}

The incidence of mental defect in premature children has been variously estimated as between 4 and 10 per cent. The incidence of severe mental defect in retrolental fibroplasia has varied from 10 to 40 per cent. in different investigations. Due regard has been given to the fact that most cases of retrolental fibroplasia are extremely premature. Despite this there seems to be a higher incidence of mental defect than is to be expected; and further investigations into this problem are needed.

\section{Summary}

At least 50 per cent. of children discharged from Sunshine Homes as "ineducable" between 1950 and 1956 suffered from retrolental fibroplasia. 
24 cases of retrolental fibroplasia in the Fountain Group of Hospitals are reviewed. Information on neonatal oxygen therapy is lacking in four cases, eighteen were nursed in oxygen tents, one received oxygen by nasal catheter at meal times only, and one did not have oxygen neonatally and was not premature. The degree of mental defect was not related to the duration of oxygen therapy.

There were no cases of cerebral palsy in the series; two cases had congenital heart lesions; in six cases there was a history of antepartum haemorrhage during the mother's pregnancy.

The incidence of mental defect in cases of retrolental fibroplasia appears to be greater than could be explained by the factor of prematurity.

I wish to acknowledge the help given to me by my colleagues at the Fountain Hospital and Mr. Colborne Brown and his staff at the Royal National Institute for the Blind.

\section{REFERENCES}

Alm, I. (1953). Acta paediat., 42, Suppl. 94.

Ashton, N., WARD, B., and Serpell, G. (1954). Brit. J. Ophthal., 38, 397.

Bedrossian, R. H., Carmichael, P., and Ritter, J. A. (1955). A.M.A. Arch. Ophthal., $53,514$. BJelkHAGEN, I. (1952). Acta paediat., 41, 74.

BOYD, J. T., and HIRST, K. M. (1955). Brit. med. J., 2, 83.

Campbell, K. (1951). Med. J. Aust., $2,48$.

Douglas, J. W. B. (1956). Brit. med. J., 1, 1210.

FISHER, R. A. (1944). "Statistical Methods for Research Workers", 9th ed. Oliver and Boyd, Edinburgh.

Forrester, R. M. (1955). M.D. Thesis, Cambridge.

FreUD, S. (1897). "Die infantile Cerebrallähmung”, in "Specielle Pathologie und Therapie", ed. H. Nothnagel, bd 9, tom 3, 2, abt. 2. Hölder, Vienna.

Hess, J. H., and LundeEn, E. C. (1949). "The Premature Infant", 2nd ed., p. 322 . Lippincott, Philadelphia.

Ingalls, T. H., Tedeschi, C. G., and Helpern, M. M. (1952). Amer. J. Ophthal., 35, 311.

INGRAM, T. T. S., and KerR, J. D. (1954). Arch. Dis. Childh., 29, 282.

KERR, J. D., and ScotT, G. I. (1954). Ibid., 29, 543.

KING, M. J. (1950). Arch. Ophthal. (Chicago), 43, 694.

KRAUSE, A. C. (1946). Ibid., 36, 387.

(1955). A.M.A. Arch. Ophthal., 53, 522.

Litrle, W. J. (1862). Trans. obstet. Soc. Lond., 3, 293.

MEDICAL RESEARCH COUNCIL REPORT (1955). Brit. med. J.,, 2, 78.

Patz, A. (1954). Amer. J. Ophthal., 38, 291.

PeIPER, (1937). Quoted by Alm (1953).

PotTer, C. T. (1954). Proc. roy. Soc. Med., 47, 715.

ReESe, A. B., and StePanik, J. (1954). Amer. J. Ophthal., 38, 308.

SZEWCZYK, T. S. (1952). Ibid., 35, 301.

YLLPO, (1919). Quoted by Alm (1953).

Zacharias, L., ReYnolds, W. E., Chisholm, J. F., and KING, M. J. (1954). Ibid., 38,, 317. 